\title{
TOWARDS METHODOLOGICAL PROBLEMS OF TROPHIC STATE ASSESSMENT OF RUNNING WATERS
}

\author{
METODOLOGICZNE PROBLEMY OCENY \\ STANU TROFICZNEGO WÓD PLYNĄCYCH
}

\begin{abstract}
Deep analysis of trophic state assessment methods has led to conclusion, that currently there is no universal methodology and existing methods are characterized by significant shortcomings. The approach proposed by the authors is different from generally used. Authors start from the assumption, that trophic state can be reflected by the state of biotic balance, which can be described by the values of Index of Trophic State. Researches were carried out in order to assess the trophic state of running waters and to estimate the limiting role of biogenic substances for eutrophication process development on the base of author's concept founded on above mentioned index.
\end{abstract}

Keywords: running water, eutrophication, methodology of assessment, biotic balance, index of trophic level

\section{Introduction}

Eutrophication is an essential and widespread progressing factor of the impact on aquatic ecosystems which practically cannot be avoided. The problem of eutrophication since the seventies of the last century takes on a global scale because of its negative consequences, which could result in total loss of economic and biospheric functions of aquatic ecosystems.

Negative consequences of eutrophication are the most vulnerable in freshwater lakes and reservoirs, but in recent decades as a result of intensive anthropogenic activity, it can be occurred more often in coastal and running waters. Deep analysis of the methods of surface water trophic state assessment has led to the conclusion, that there is currently no universal methodology and existing methods are characterized by significant shortcomings that lead to low reliability of the results.

Eutrophication processes are characterized by high dynamism and the dependence on complex of different factors, such as: hydrological and hydrodynamics characteristics; hydrobiological and morphological features; edaphic and climatic conditions. So, the assessment of trophic status of different types of waters is rather complicated task.

\footnotetext{
${ }^{1}$ Department of Management and Protection of Environment, AGH University of Science and Technology, al. A. Mickiewicza 30, 30-059 Krakow, Poland, phone +48 126174704

*Corresponding author: elenad@agh.edu.pl
} 
In European Union water policy the problem of eutrophication is regarded as a priority issue. Many EU directives contain a requirement of assessment and control of this process and the necessity of water protection measures implementation in order to prevent its development. These requirements are contained, for example, in Directive 91/271/EEC (Directive on Urban Waste Water Treatment), Directive 91/676/EEC (Directive concerning the nitrates from agricultural land) and Directive 2000/60/EEC (Water Framework Directive). These directives contain neither uniform definition of eutrophication, no universal approach for assessing the trophic state [1-3].

In Poland the requirements of EU directives are reflected in the Water Act and three Regulations of the Minister of Environment, according to which the evaluation of trophic status is carried out on the base of traditional indicators in the frames of general water state assessment, and only in terms: "subjected to eutrophication" or "not subjected to eutrophication". Moreover, different Regulations contain divergent normative values of eutrophication indicators [4-6].

Analysis of methodological problems in the sphere of eutrophication assessment in different types of water bodies allowed confirming the necessity of the development and application of such indicators of trophic state that correspond to the objectives and tasks of water protection and water management. Modern requirements for such environmental indicators are the following: they must be theoretically and technically founded; to reflect the changes in aquatic ecosystems; to reflect the fundamental functions of aquatic ecosystems; to integrate information in time and space; to be based on a limited number of parameters; to be useful for forecasting of the aquatic environment changes and to be lowcost $[7,8]$.

\section{Eutrophication of streams and rivers}

The hydrographic network of any basin is dominated by medium and small rivers, which are highly dependent on situation in the catchment; meanwhile anthropogenic activity in this area greatly impacts the state of river ecosystems. Not long ago the primary sources of river pollution were urban and industrial wastewaters. In recent years the pollution loads from point sources have been decreased due to the construction and modernization of wastewater treatment plants, but at the same time, the share of run-off from agricultural lands and adversely effects of navigation and hydropower increased.

Length of the river network in Poland is quite large and amounts $74714 \mathrm{~km}, 52 \%$ of which are regulated rivers. Positive feature of river regulation is responding the economy needs, however such a drastic interference into environment leads to the loss of natural values of the river, changes of structure of riverine biota, and consequently - to decrease of self-purification ability, progressing eutrophication and secondary contamination.

Eutrophication process pattern is best studied in stagnant waters - lakes, ponds and coastal areas. Definitely the majority of trophic status evaluation methods are also developed for these waters. Much less is known the eutrophication processes in running water ecosystems which are functioning in different way due to the following specific features:

- $\quad$ flow of water, which plays a significant role as a limiting factor of eutrophication;

- more intensive exchange between water and land, that makes the rivers to be an "open ecosystem" with heterotrophic type of metabolism; 
- more uniform distribution of dissolved oxygen in rivers and therefore the lack of thermal or chemical stratification [9].

Specific features of river ecosystems condition the different course of eutrophication process as compared to limnetic ecosystems, and therefore it cannot be described accurately on the basis of methods established for lakes and coastal areas.

Current concept of eutrophication in running waters is focuses mainly on water enrichment in nitrogen and phosphorus compounds [10-12]. Earlier research on eutrophication in rivers focused on the discharge of organic matter together with raw wastewater and agricultural run-off $[13,14]$. In the last 30 years the studies were carried out to determine the relation between the nutrient loads discharged to rivers and the development of autotrophic organisms.

Limnological studies allowed to establish a clear correlation between the enrichment of lake water in nitrogen and phosphorus and the increase of plant biomass. Also the leading role of phosphorus in stimulation of autotrophic processes was established. This allowed the determination of the basic traditional indicators of eutrophication: nutrients and chlorophyll content. Correll [15] wrote that the excess of phosphorus is the most common cause of eutrophication in freshwater lakes, reservoirs, rivers and estuarine waters. However, this statement was not based on specific research and empirical observations of lotic ecosystems. Therefore, the methods of trophic status assessment elaborated mainly for lentic ecosystems are not always reliable in the case of trophic status evaluation of running waters.

\section{Materials and methods}

The approach proposed by the authors of this paper is different from generally used methods, which focus mainly on nitrogen and phosphorus enrichment and primary production. The proposed method starts from the assumption, that trophic state can be reflected by the state of biotic balance, i.e. the balance between the processes of production and destruction of organic matter synthesized by water plants. Hence, the indicator of trophic status of aquatic ecosystem should reflect the integral result of processes of organic matter production and destruction. Similar view is presented also by other authors [16-19].

Dystrophic waters are characterized by exceeding of organic matter decomposition rate $\left(V_{d}\right)$ in relation to the rate of its production $\left(V_{p}\right)$ and then $V_{p} / V_{d}<1$; while oligotrophic are characterized by the balanced rates of these processes: $V_{p} / V_{d} \approx 1$; and in waters subjected to eutrophication the rate of organic matter production is higher than the rate of decomposition, so $V_{p} / V_{d}>1$ [20].

It can therefore be assumed that the criterion, which most adequately reflects the trophic status of surface waters, is the indicator of the balance of production and decomposition of organic matter, ie, biotic balance.

Index of trophic status of waters ITS (Index of Trophic State) based on theoretical assumptions, according to which the imbalance of the rates of water vegetation production and its decomposition in any water ecosystems leads primarily to changes in the quantitative ratios of the concentrations of $\mathrm{O}_{2}$ and $\mathrm{CO}_{2}[17,18]$.

When the rate of organic matter decomposition exceeds of rate of its production, concentration of $\mathrm{CO}_{2}$ in water increases, and concentration of $\mathrm{O}_{2}$ decreases and vice versa. From this it follows that the ratio of $\mathrm{CO}_{2}$ and $\mathrm{O}_{2}$ concentration in water environment 
represents the relationship between the rates of organic matter production and decomposition processes, ie the state of biotic balance, as follows also from photosynthesis balance equation:

$$
n \mathrm{CO}_{2}+n \mathrm{H}_{2} \mathrm{O} \underset{V_{d}}{\stackrel{V_{p}}{\longleftrightarrow}}\left(\mathrm{CH}_{2}\right)_{n}+n \mathrm{O}_{2}
$$

where: $V_{p}$ and $V_{d}$ - rates of production (photosynthesis) and decomposition processes, $n$ - number of molecules participating in the reaction.

In aquatic ecosystems the ratio of $\mathrm{CO}_{2}$ and $\mathrm{O}_{2}$ concentrations can be expressed by the ratio of $\mathrm{pH}$ and saturation of water with oxygen, which results from the following considerations. According to the chemical Law of Mass Action of C.M. Guldberg and P. Waage defining the chemical equilibrium depending on the concentration of reactants and reaction products, it can be presented as equations (2)-(6) [21]:

$$
V_{p}=k_{1}\left[\mathrm{CO}_{2}\right]^{n}\left[\mathrm{H}_{2} \mathrm{O}\right]^{n} \text {, and } V_{d}=k_{2}\left[\mathrm{CH}_{2} \mathrm{O}\right]^{n}\left[\mathrm{O}_{2}\right]^{n}
$$

Whence:

$$
V_{p} / V_{d}=k_{1}\left[\mathrm{CO}_{2}\right]^{n}\left[\mathrm{H}_{2} \mathrm{O}\right]^{n} / k_{2}\left[\mathrm{CH}_{2} \mathrm{O}\right]^{n}\left[\mathrm{O}_{2}\right]^{n}
$$

where: $k_{1}$ and $k_{2}$ - rate constants of production and decomposition respectively, $n$ - concentration of the reactants.

In accordance with the same law concentrations of reactants in individual phases are fixed and do not affect the rate of a chemical reaction and then:

$$
\left[\mathrm{H}_{2} \mathrm{O}\right]=\left[\mathrm{CH}_{2} \mathrm{O}\right]=\text { const and } V_{p} / V_{d}=k_{1}\left[\mathrm{CO}_{2}\right]^{n} / k_{2}\left[\mathrm{O}_{2}\right]^{n}
$$

In surface water of low dissolved salt content the changes of $\mathrm{CO}_{2}$ concentrations lead to the changes of $\mathrm{pH}$ values, because the content of carbon dioxide and hydrogen in aquatic environment are linked together by carbonate equilibrium, that is, the certain proportion between the concentrations of carbonates and bicarbonates:

$$
\mathrm{CO}_{2}+\mathrm{H}_{2} \leftrightarrow \mathrm{H}^{+}+\mathrm{HCO}_{3}^{-} \leftrightarrow \mathrm{H}^{+}+\mathrm{CO}_{3}^{2-}
$$

The change in $\mathrm{CO}_{2}$ concentration in surface water leads to displacement of carbonate equilibrium and hydrogen ion concentration changes, and thus the $\mathrm{pH}$ value. Natural waters due to the content of the carbonic acid salts have good buffering properties:

$$
\mathrm{CO}_{2}+\mathrm{H}_{2} \mathrm{O}+\mathrm{CaCO}_{3} \leftrightarrow \mathrm{Ca}\left(\mathrm{HCO}_{3}\right)
$$

In conditions of $\mathrm{CO}_{2}$ excess the carbonates are dissolving, and in its absence - are settling. Under sufficient buffer capacity the $\mathrm{pH}$ value fluctuations are negligible and its value is in the range 6.5-8.5. It is these $\mathrm{pH}$ values are taken as normative for fresh surface water. In some cases, the $\mathrm{pH}$ value may differ from the standard values and be less than 5.0 due to a low mineralization and the presence of humic acids. The same can be observed in the high mountain lakes. In hard water $\mathrm{pH}$ is typically greater than 7 , and in salt waters above 8 [21].

The $\mathrm{pH}$ value corresponding to carbon dioxide content under carbon equilibrium (ie the part of dissolved free $\mathrm{CO}_{2}$, determining the maintenance of the dissolved bicarbonates) is called the $\mathrm{pH}$ of carbon equilibrium ( $\mathrm{pHS}$ ). 
During eutrophication the biotic balance may be disturbed (as the result of organic matter production). Then the $\mathrm{CO}_{2}$ concentration decreases and the $\mathrm{pH}$ values exceed the values of pHS. In the case of toxic pollution or nutrient deficiency the opposite changes can be observed. The same can be occurred in winter in the absence of photosynthesis, when the process of $\mathrm{CO}_{2}$ accumulation takes place, the $\mathrm{pH}$ value decreases. These processes are simultaneously accompanied by corresponding increase or decrease of water saturation by oxygen, and thus: under intensive photosynthesis it is over $100 \%$, and under inhibition of photosynthesis it falls below $100 \%[21,22]$.

Empirically it was established that in low-mineralized oligotrophic waters the oxygen content is mainly conditioned by atmospheric aeration and corresponds to its maximum solubility at specific pressures and temperatures, ie reaches $100 \%$ of saturation at $\mathrm{pH} \approx 7.0 \mathrm{pHS}[20]$.

When water is polluted by acidic or alkaline industrial wastewaters the changes of $\mathrm{pH}$ value are not accompanied by changes of oxygen saturation and $\mathrm{pH}$ values quickly return to normal thanks to the buffer properties of natural waters [21, 23].

In the light of this assumption the problem seems to be the choice of indicator, which reflects the balance between the production and destruction of organic matter in surface waters during the annual cycle. The authors propose to use the criterion ITS (Index of Trophic State) elaborated by Neverova-Dziopak, which is based on the above mentioned theoretical assumptions. Index of Trophic State can be calculated according to equation (7):

$$
\mathrm{ITS}=\sum \mathrm{pH}_{\mathrm{i}} / n+a\left(100-\sum\left[\mathrm{O}_{2} \%\right] / n\right)
$$

where: $\mathrm{pH}_{\mathrm{i}}-\mathrm{pH}$ value; $\left[\mathrm{O}_{2} \%\right]$ - oxygen saturation measured synchronously with $\mathrm{pH}$; $a$ - an empirical coefficient; $n$ - number of measurements [21].

The state of biotic balance and the values of ITS in waters of different trophic conditions are shown in Table 1.

Values of ITS in fresh waters of different trophic state [21]

\begin{tabular}{|c|c|c|}
\hline State of biotic balance $\left(\boldsymbol{V}_{p} / \boldsymbol{V}_{\boldsymbol{d}}\right)$ & Trophic state & ITS \\
\hline Negative & Dystrophic & $<.7 \pm 0.3$ \\
$\left(V_{p} / V_{d}<1\right)$ & Ultraoligotrophic & $6.3 \pm 0.3$ \\
\hline Balanced & Ologotrophic & $7.0 \pm 0.3$ \\
$\left(V_{p} / V_{d}=1\right)$ & Mezotrophic & $7.7 \pm 0.3$ \\
\hline Positive & Eutrophic & $>8.3 \pm 0.3$ \\
\hline
\end{tabular}

The researches ware carried out in order to use Index of Trophic State for the purposes of trophic state assessment of running waters. The studies on the limiting factors of this process were also carried out on the base of ITS. The assessment was realized for different types of running waters determined in Poland according to Frame Water Directive [1]. There were appointed 26 types of courses in Poland, among them are: 3 types of mountain streams, 12 types of upland rivers, 7 types of lowland rivers, 4 types of rivers independent on ecoregion and group of indefinite types.

The researches were carried out for selected measurement points located on the rivers of different types on the base of long-term monitoring database obtained in the frames of Polish State Monitoring System (Table 2). 
Measurement points analyzed in the research

\begin{tabular}{|c|c|c|c|}
\hline $\begin{array}{l}\text { Type of } \\
\text { the river }\end{array}$ & Measurement point & $\begin{array}{c}\text { Period of } \\
\text { monitoring }\end{array}$ & Description of river type \\
\hline 5 & $\begin{array}{c}\text { Katowice Bolina before Przemsza } \\
0.3 \mathrm{~km}\end{array}$ & 2000-2009 & $\begin{array}{l}\text { Upland landscape: small silicate stream with } \\
\text { fine-grained substrate }\end{array}$ \\
\hline 6 & Kielce Silnica Bialogon 0.9 km & 2000-2009 & $\begin{array}{l}\text { Upland landscape: small carbonate stream } \\
\text { with fine-grained substrate }\end{array}$ \\
\hline 9 & $\begin{array}{c}\text { Krakow Rudawa Podkamycze } \\
9.3 \mathrm{~km}\end{array}$ & 2000-2009 & Upland landscape: small carbonate river \\
\hline 10 & Lodz Pilica Sulejow 159.8 km & $2000-2009$ & Upland landscape: middle river \\
\hline 14 & $\begin{array}{c}\text { Krakow Czarna Orawa Jablonka } \\
25 \mathrm{~km}\end{array}$ & 2000-2009 & $\begin{array}{c}\text { Upland landscape: small river on flysc } \\
\text { structures }\end{array}$ \\
\hline 17 & $\begin{array}{c}\text { Bialystok Krynka - boundary } \\
\text { profile } 4.5 \mathrm{~km}\end{array}$ & 2000-2009 & Lowland landscape: small sand stream \\
\hline 20 & Olsztyn Guber Sepopol 76 km & $2000-2009$ & Lowland landscape: medium gravel river \\
\hline 21 & Warszawa Narew Pultusk 64 km & $2000-2008$ & Lowland landscape: great river in the plains \\
\hline 22 & $\begin{array}{l}\text { Gdansk Lupawa Rowy } \\
0.7 \mathrm{~km} \\
\end{array}$ & 2001-2009 & $\begin{array}{c}\text { Estuary part of the river under the influence } \\
\text { of saline water }\end{array}$ \\
\hline 23 & $\begin{array}{c}\text { Lublin Czyzowka Janow Podlaski } \\
4.2 \mathrm{~km}\end{array}$ & 2000-2009 & $\begin{array}{l}\text { Small streams in the valleys or large lowland } \\
\text { rivers under the influence of peat-forming } \\
\text { processes }\end{array}$ \\
\hline 24 & $\begin{array}{c}\text { Zielona Gora Pliszka before Odra } \\
0.3 \mathrm{~km}\end{array}$ & 2000-2008 & $\begin{array}{c}\text { Small rivers in the valleys or large lowland } \\
\text { rivers under the influence of peat-forming } \\
\text { processes }\end{array}$ \\
\hline
\end{tabular}

The results of comparative trophic state assessment carried out on the base of ITS and boundary values of traditional indices, elaborated by different authors, presented in Table 3 . The assessment was made on the base of average annual values of parameters measured during 10-year monitoring period [24].

Table 3

Results of comparative trophic state assessment in measurement points*

\begin{tabular}{|c|c|c|c|c|c|c|c|c|c|c|c|c|}
\hline & Type of the river & 5 & 6 & 9 & 10 & 14 & 17 & 20 & 21 & 22 & 23 & 24 \\
\hline \multirow{18}{*}{ 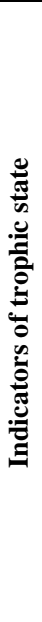 } & ITS value & $\mathrm{m}$ & $\mathrm{e}$ & $\mathrm{m}$ & $\mathrm{e}$ & $\mathrm{e}$ & $\mathrm{m}$ & $\mathrm{e}$ & $\mathrm{e}$ & $\mathrm{e}$ & $\mathrm{m}$ & $\mathrm{m}$ \\
\hline & $\mathrm{N}$ - Burns & e & $\mathrm{e}$ & $\mathrm{e}$ & $\mathrm{e}$ & e & $\mathrm{e}$ & $\mathrm{e}$ & $\mathrm{e}$ & e & $\mathrm{e}$ & $\mathrm{e}$ \\
\hline & P-Burns & $\mathrm{e}$ & $\mathrm{e}$ & $\mathrm{e}$ & $\mathrm{e}$ & $\mathrm{e}$ & $\mathrm{e}$ & $\mathrm{e}$ & $\mathrm{e}$ & $\mathrm{e}$ & $\mathrm{e}$ & $\mathrm{e}$ \\
\hline & Chl-a - Burns & $\mathrm{e}$ & $\mathrm{e}$ & $\mathrm{m}$ & $\mathrm{e}$ & $\mathrm{m}$ & $\mathrm{m}$ & $\mathrm{e}$ & $\mathrm{e}$ & $\mathrm{e}$ & $\mathrm{e}$ & $\mathrm{e}$ \\
\hline & P - Carlson & $\mathrm{e}$ & $\mathrm{e}$ & $\mathrm{e}$ & $\mathrm{e}$ & e & $\mathrm{e}$ & $\mathrm{e}$ & $\mathrm{e}$ & $\mathrm{e}$ & $\mathrm{e}$ & $\mathrm{e}$ \\
\hline & Chl-a - Carlson & $\mathrm{m}$ & $\mathrm{e}$ & 0 & $\mathrm{~m}$ & o & $\mathrm{m}$ & $\mathrm{m}$ & $\mathrm{e}$ & $\mathrm{e}$ & $\mathrm{m}$ & $\mathrm{m}$ \\
\hline & P - Chapra Dobson & $\mathrm{e}$ & $\mathrm{e}$ & $\mathrm{e}$ & $\mathrm{e}$ & $\mathrm{e}$ & $\mathrm{e}$ & $\mathrm{e}$ & $\mathrm{e}$ & $\mathrm{e}$ & $\mathrm{e}$ & $\mathrm{e}$ \\
\hline & Chl-a Chapra Dobson & $\mathrm{m}$ & $\mathrm{e}$ & $\mathrm{o}$ & $\mathrm{m}$ & $\mathrm{m}$ & $\mathrm{m}$ & $\mathrm{e}$ & $\mathrm{e}$ & $\mathrm{e}$ & $\mathrm{e}$ & $\mathrm{e}$ \\
\hline & P - DillonRigler & $\mathrm{e}$ & $\mathrm{e}$ & $\mathrm{e}$ & $\mathrm{e}$ & $\mathrm{e}$ & $\mathrm{e}$ & $\mathrm{e}$ & $\mathrm{e}$ & $\mathrm{e}$ & $\mathrm{e}$ & $\mathrm{e}$ \\
\hline & Chl-a - DillonRigler & $\mathrm{e}$ & $\mathrm{e}$ & $\mathrm{m}$ & $\mathrm{e}$ & $\mathrm{m}$ & $\mathrm{m}$ & $\mathrm{e}$ & $\mathrm{e}$ & $\mathrm{e}$ & $\mathrm{e}$ & $\mathrm{e}$ \\
\hline & $\mathrm{N}$ - Dodds & $\mathrm{e}$ & $\mathrm{e}$ & $\mathrm{e}$ & $\mathrm{e}$ & $\mathrm{m}$ & $\mathrm{e}$ & $\mathrm{e}$ & $\mathrm{e}$ & $\mathrm{e}$ & $\mathrm{e}$ & $\mathrm{m}$ \\
\hline & $\mathrm{P}$ - Dodds & $\mathrm{e}$ & $\mathrm{e}$ & $\mathrm{e}$ & $\mathrm{e}$ & $\mathrm{m}$ & $\mathrm{e}$ & $\mathrm{e}$ & $\mathrm{e}$ & $\mathrm{e}$ & $\mathrm{e}$ & $\mathrm{e}$ \\
\hline & Chl-a - Dodds & o & $\mathrm{m}$ & 0 & 0 & o & $\mathrm{o}$ & $\mathrm{m}$ & $\mathrm{m}$ & $\mathrm{e}$ & 0 & $\mathrm{~m}$ \\
\hline & N - Forsberg Ryding & $\mathrm{e}$ & $\mathrm{e}$ & $\mathrm{e}$ & $\mathrm{e}$ & $\mathrm{e}$ & $\mathrm{e}$ & $\mathrm{e}$ & $\mathrm{e}$ & $\mathrm{e}$ & $\mathrm{e}$ & $\mathrm{e}$ \\
\hline & P - Forsberg Ryding & $\mathrm{e}$ & $\mathrm{e}$ & $\mathrm{e}$ & $\mathrm{e}$ & $\mathrm{e}$ & $\mathrm{e}$ & $\mathrm{e}$ & $\mathrm{e}$ & $\mathrm{e}$ & $\mathrm{e}$ & $\mathrm{e}$ \\
\hline & Chl-a - Ryding & $\mathrm{m}$ & $\mathrm{e}$ & 0 & $\mathrm{~m}$ & $\mathrm{o}$ & 0 & $\mathrm{e}$ & $\mathrm{e}$ & $\mathrm{e}$ & $\mathrm{m}$ & $\mathrm{e}$ \\
\hline & P- OECD & $\mathrm{e}$ & $\mathrm{e}$ & $\mathrm{e}$ & $\mathrm{e}$ & $\mathrm{e}$ & $\mathrm{e}$ & $\mathrm{e}$ & $\mathrm{e}$ & $\mathrm{e}$ & $\mathrm{e}$ & $\mathrm{e}$ \\
\hline & Chl-a - OECD & $\mathrm{m}$ & $\mathrm{e}$ & $\mathrm{o}$ & $\mathrm{m}$ & $\mathrm{m}$ & $\mathrm{m}$ & $\mathrm{e}$ & $\mathrm{e}$ & $\mathrm{e}$ & $\mathrm{e}$ & $\mathrm{e}$ \\
\hline
\end{tabular}




\begin{tabular}{|c|c|c|c|c|c|c|c|c|c|c|c|c|}
\hline & Type of the river & $\mathbf{5}$ & $\mathbf{6}$ & $\mathbf{9}$ & $\mathbf{1 0}$ & $\mathbf{1 4}$ & $\mathbf{1 7}$ & $\mathbf{2 0}$ & $\mathbf{2 1}$ & $\mathbf{2 2}$ & $\mathbf{2 3}$ & $\mathbf{2 4}$ \\
\hline P - New Hampshire & $\mathrm{e}$ & $\mathrm{e}$ & $\mathrm{e}$ & $\mathrm{e}$ & $\mathrm{e}$ & $\mathrm{e}$ & $\mathrm{e}$ & $\mathrm{e}$ & $\mathrm{e}$ & $\mathrm{e}$ & $\mathrm{e}$ \\
\hline Chl-a - New Hampshire & $\mathrm{m}$ & $\mathrm{e}$ & $\mathrm{o}$ & $\mathrm{m}$ & $\mathrm{o}$ & $\mathrm{o}$ & $\mathrm{m}$ & $\mathrm{e}$ & $\mathrm{e}$ & $\mathrm{m}$ & $\mathrm{m}$ \\
\hline $\mathrm{N}-$ Nurnberg & $\mathrm{e}$ & $\mathrm{e}$ & $\mathrm{e}$ & $\mathrm{e}$ & $\mathrm{e}$ & $\mathrm{e}$ & $\mathrm{e}$ & $\mathrm{e}$ & $\mathrm{e}$ & $\mathrm{e}$ & $\mathrm{e}$ \\
\hline P - Nurnberg & $\mathrm{e}$ & $\mathrm{e}$ & $\mathrm{e}$ & $\mathrm{e}$ & $\mathrm{e}$ & $\mathrm{e}$ & $\mathrm{e}$ & $\mathrm{e}$ & $\mathrm{e}$ & $\mathrm{e}$ & $\mathrm{e}$ \\
\hline Chl-a - Nurnberg & $\mathrm{m}$ & $\mathrm{e}$ & $\mathrm{o}$ & $\mathrm{m}$ & $\mathrm{o}$ & $\mathrm{m}$ & $\mathrm{e}$ & $\mathrm{e}$ & $\mathrm{e}$ & $\mathrm{e}$ & $\mathrm{e}$ \\
\hline $\mathrm{N}-$ Vant & $\mathrm{e}$ & $\mathrm{e}$ & $\mathrm{e}$ & $\mathrm{e}$ & $\mathrm{e}$ & $\mathrm{e}$ & $\mathrm{e}$ & $\mathrm{e}$ & $\mathrm{e}$ & $\mathrm{e}$ & $\mathrm{e}$ \\
\hline P - Vant & $\mathrm{e}$ & $\mathrm{e}$ & $\mathrm{e}$ & $\mathrm{e}$ & $\mathrm{e}$ & $\mathrm{e}$ & $\mathrm{e}$ & $\mathrm{e}$ & $\mathrm{e}$ & $\mathrm{e}$ & $\mathrm{e}$ \\
\hline Chl-a - Vant & $\mathrm{e}$ & $\mathrm{e}$ & $\mathrm{o}$ & $\mathrm{e}$ & $\mathrm{o}$ & $\mathrm{o}$ & $\mathrm{e}$ & $\mathrm{e}$ & $\mathrm{e}$ & $\mathrm{e}$ & $\mathrm{e}$ \\
\hline P - Vollenweider & $\mathrm{e}$ & $\mathrm{e}$ & $\mathrm{e}$ & $\mathrm{e}$ & $\mathrm{e}$ & $\mathrm{e}$ & $\mathrm{e}$ & $\mathrm{e}$ & $\mathrm{e}$ & $\mathrm{e}$ & $\mathrm{e}$ \\
\hline Chl-a - Vollenweider & $\mathrm{m}$ & $\mathrm{e}$ & $\mathrm{m}$ & $\mathrm{m}$ & $\mathrm{m}$ & $\mathrm{m}$ & $\mathrm{e}$ & $\mathrm{e}$ & $\mathrm{e}$ & $\mathrm{e}$ & $\mathrm{e}$ \\
\hline P - Welch Lindell & $\mathrm{e}$ & $\mathrm{e}$ & $\mathrm{e}$ & $\mathrm{e}$ & $\mathrm{e}$ & $\mathrm{e}$ & $\mathrm{e}$ & $\mathrm{e}$ & $\mathrm{e}$ & $\mathrm{e}$ & $\mathrm{e}$ \\
\hline Chl-a - Welch Lindell & $\mathrm{o}$ & $\mathrm{m}$ & $\mathrm{o}$ & $\mathrm{o}$ & $\mathrm{o}$ & $\mathrm{o}$ & $\mathrm{o}$ & $\mathrm{m}$ & $\mathrm{e}$ & $\mathrm{o}$ & $\mathrm{m}$ \\
\hline
\end{tabular}

*o - oligotrophic conditions, $\mathrm{m}$ - mesotrophic conditions, e - eutrophic conditions

\section{Results of the research}

Analysis of Table 3 shows high compliance of assessments made on the basis of ITS and boundary values of traditional indicators of eutrophication, developed by different authors. On the base of the assessment conducted by ITS for selected points located on rivers of 5, 9, 17, 23 and 24 types, it can be concluded, that these measurement points belong to mesotrophic waters. However, water in the points located on the rivers of 6,10 , 14, 20, 21 and 22 types are characterized as eutrophic. Wherein, the measurement points located on small silicate streams and carbonate rivers of upland landscape, small sandy rivers of lowland landscape and small streams and rivers in the peaty areas were classified as mesotrophic waters. Waters in the points on small and medium rivers of upland landscape, medium and large rivers of plains and estuarine rivers under the influence of saline waters were classified as eutrophic waters. Trophic state assessment realized on the base of ITS index allowed to follow the long-term dynamics of trophic level in selected measurement points (Figs. 1, 2).

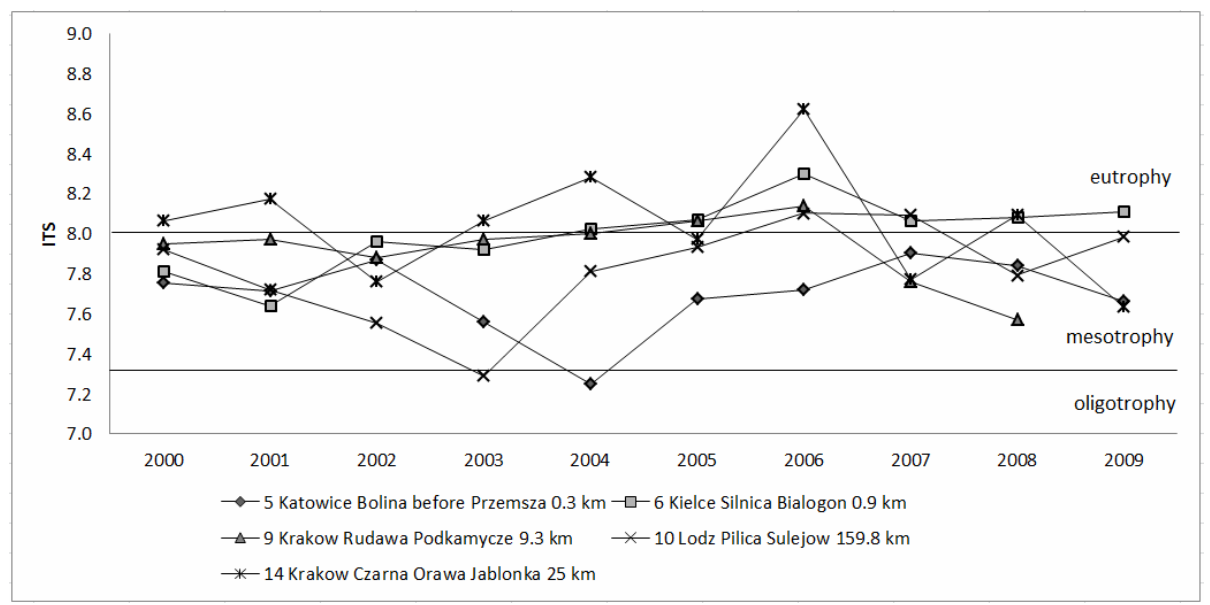

Fig. 1. Long-term dynamics of trophic level in measurement points on upland rivers 


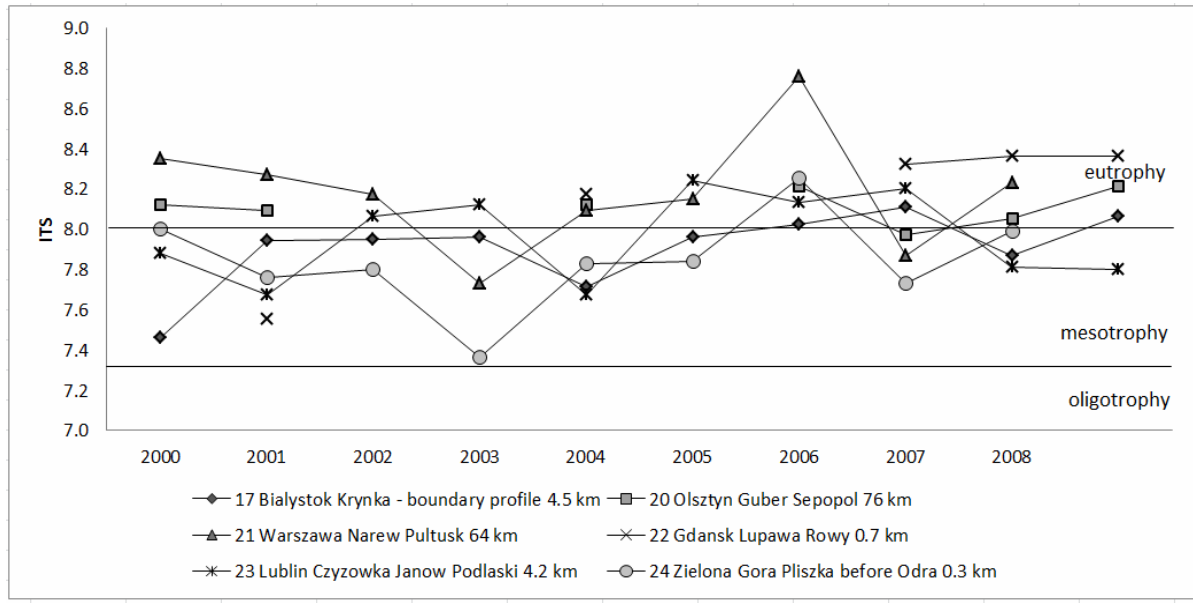

Fig. 2. Long-term dynamics of trophic level in measurement points on lowland rivers

The authors of the paper also made an attempt to determine the role of total forms of nitrogen and phosphorus in eutrophication process development in rivers. The database consisted of average annual values of $\mathrm{pH}$, oxygen saturation, total nitrogen and total phosphorus measured in the mentioned points during monitoring period of 2000-2010. For this purpose a preliminary statistical analysis of correlation between ITS and concentrations of total nitrogen and phosphorus was carried out. The values of Pearson's correlation coefficient characterizing the relationship between ITS and total nitrogen and total phosphorus content are presented in Table 4.

Table 4

Pearson's correlation coefficient value

\begin{tabular}{|c|c|c|c|}
\hline $\begin{array}{c}\text { Type of } \\
\text { the river }\end{array}$ & Measurement point & $\begin{array}{c}\text { Total } \\
\text { nitrogen }\end{array}$ & $\begin{array}{c}\text { Total } \\
\text { phosphorus }\end{array}$ \\
\hline 5 & Katowice Bolina before Przemsza $0.3 \mathrm{~km}$ & -0.29 & 0.04 \\
\hline 6 & Kielce Silnica Bialogon 0.9 km & -0.31 & -0.31 \\
\hline 9 & Krakow Rudawa Podkamycze $9.3 \mathrm{~km}$ & 0.26 & 0.76 \\
\hline 10 & Lodz Pilica Sulejow $159.8 \mathrm{~km}$ & -0.33 & -0.61 \\
\hline 14 & Krakow Czarna Orawa Jablonka $25 \mathrm{~km}$ & 0.17 & -0.02 \\
\hline 17 & Bialystok Krynka - bondary profile $4.5 \mathrm{~km}$ & -0.80 & -0.32 \\
\hline 20 & Olsztyn Guber Sepopol 76 km & -0.50 & -0.47 \\
\hline 21 & Warszawa Narew Pultusk 64 km & -0.56 & 0.03 \\
\hline 22 & Gdansk Lupawa Rowy 0.7 km & -0.06 & -0.33 \\
\hline 23 & Lublin Czyzowka Janow Podlaski $4.2 \mathrm{~km}$ & 0.39 & -0.09 \\
\hline 24 & Zielona Gora Pliszka before Odra $0.3 \mathrm{~km}$ & 0.09 & 0.35 \\
\hline
\end{tabular}

Analysis of the data from Table 3 made it possible to draw the following conclusions. Virtually none of measurement points showed nitrogen-limiting role in the development of eutrophication. An exception may be a measurement point on the lowland river of type 23 and in some degree - on the river of type 9. In the majority of the points total nitrogen contributed rather to the repression of development of eutrophication. In the points located 
on the rivers of type 14, 22 and 24 practically no nitrogen influence on eutrophication was obtained.

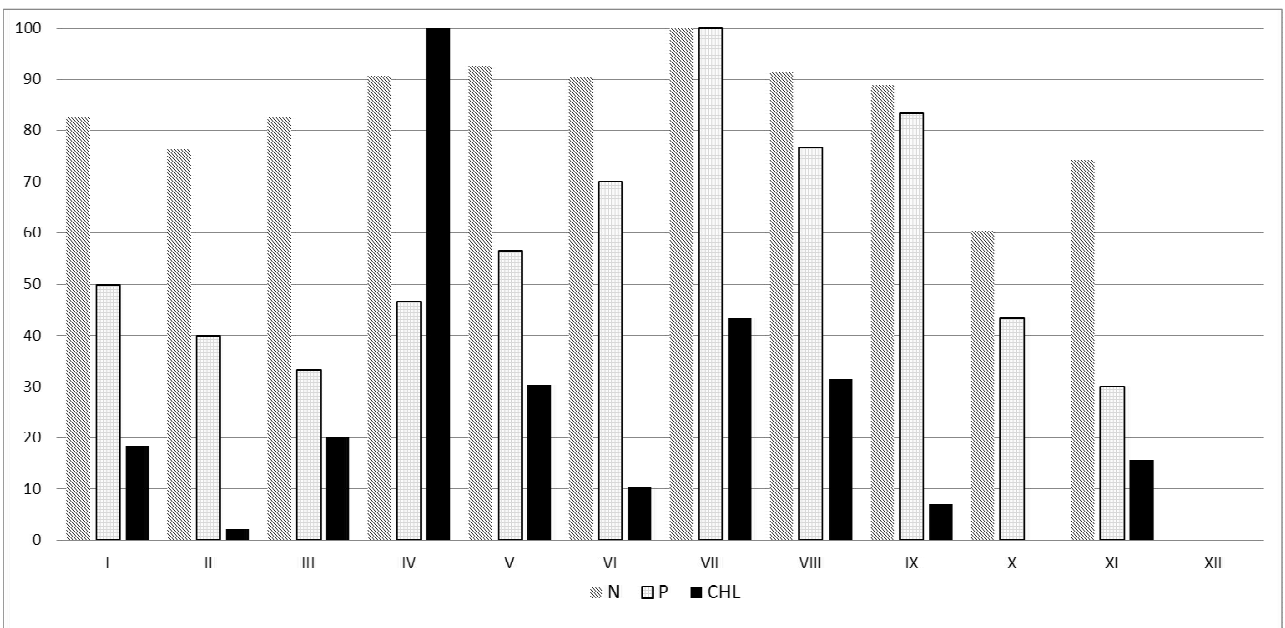

Fig. 3. Seasonal dynamics of nitrogen, phosphorus and chlorophyll in 2002 (type 9, Krakow Rudawa Podkamycze $9.3 \mathrm{~km}$ )

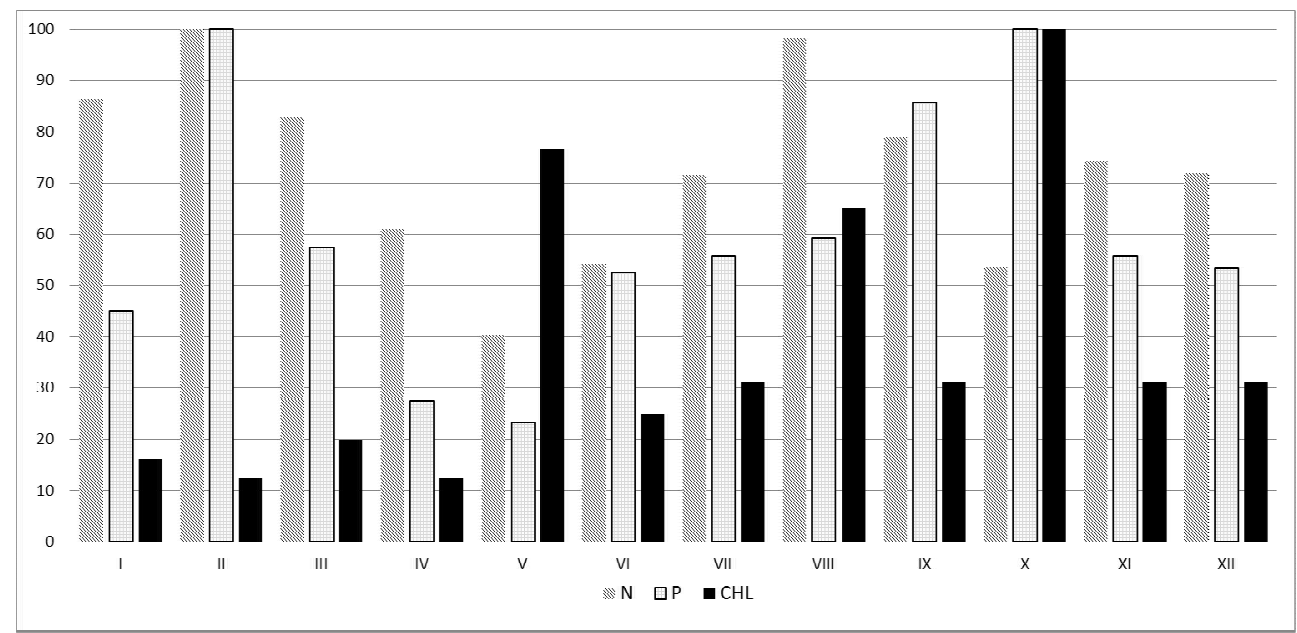

Fig. 4. Seasonal dynamics of nitrogen, phosphorus and chlorophyll in 2006 (type 14, Krakow Czarna Orawa Jablonka $25 \mathrm{~km}$ )

The limiting role of total phosphorus was stated in measurement points located on the rivers of 5, 14, 21 and 23 types. However, a significant correlation between ITS and phosphorus was observed in the points on the river of 9 and 24 types. In the remaining points total phosphorus showed rather inhibitory effect on eutrophication. Only in the measurement point located on the river of type 9 it was observed the limiting role of total nitrogen and phosphorus, wherein total phosphorus plays the key role. Such relationship in 
this point shows similarity with the traditional regularities of eutrophication process in limnetic waters.

Percentage monthly changes of chlorophyll together with total nitrogen and phosphorus content for the selected measurement points are shown in Figures 3-7.

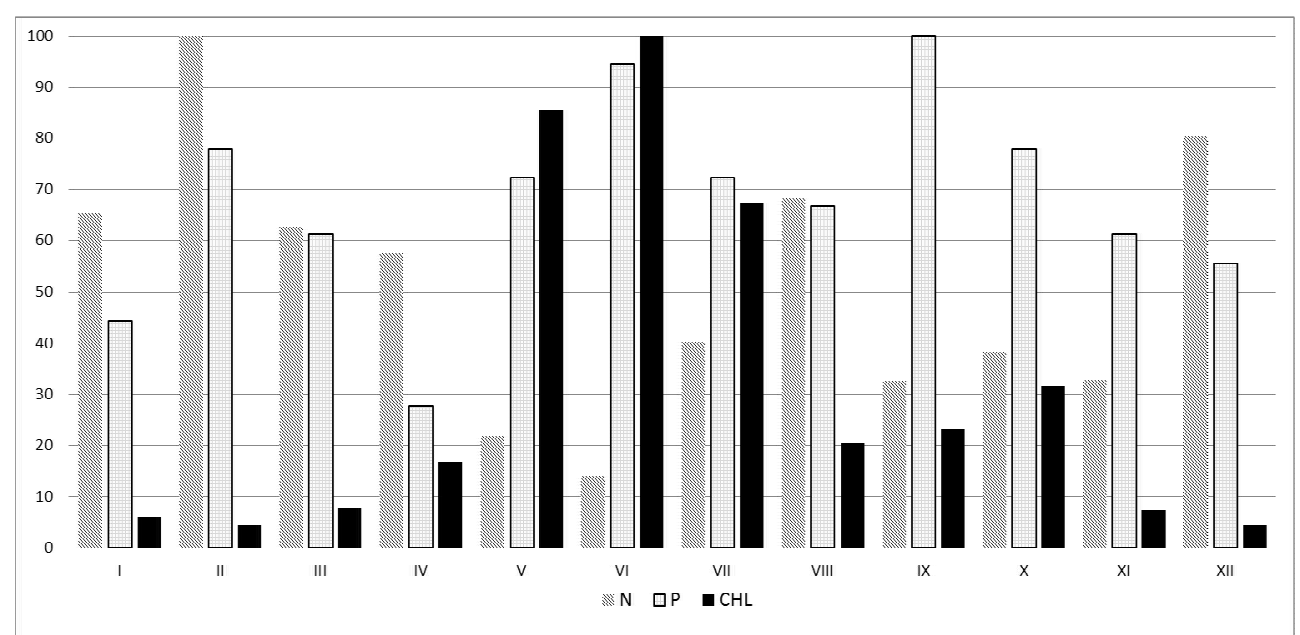

Fig. 5. Seasonal dynamics of nitrogen, phosphorus and chlorophyll in 2007 (type 21, Warszawa Narew Pultusk $64 \mathrm{~km}$ )

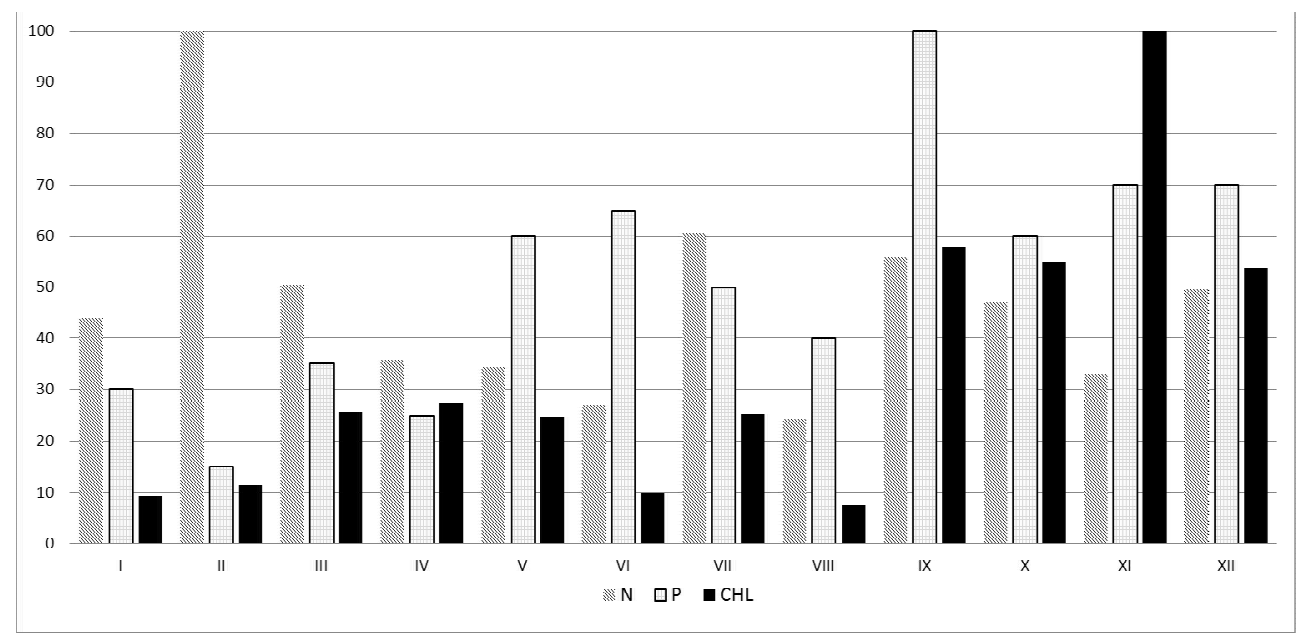

Fig. 6. Seasonal dynamics of nitrogen, phosphorus and chlorophyll in 2001 (type 22, Gdansk Lupawa Rowy 0.7 km) 


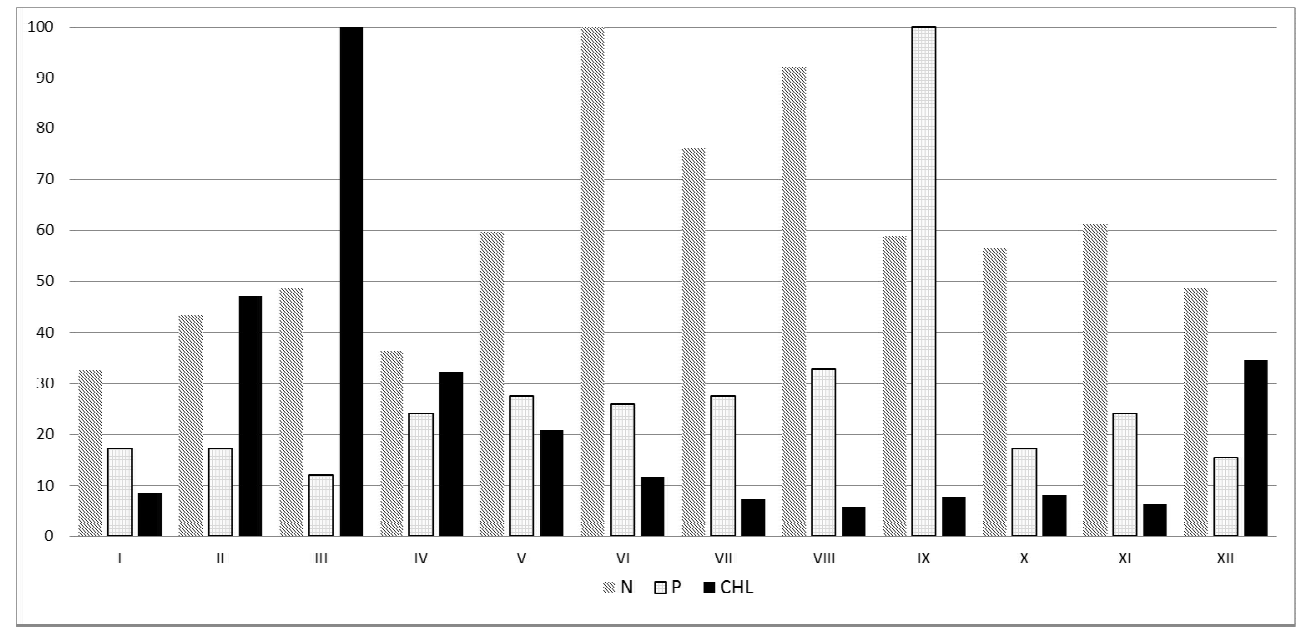

Fig. 7. Seasonal dynamics of nitrogen, phosphorus and chlorophyll in 2002 (type 24, Zielona Gora Pliszka before Odra $0.3 \mathrm{~km}$ )

\section{Discussion}

The conducted studies showed that the examined water monitoring points are characterized by a high content of total nitrogen and phosphorus, qualifying these waters as eutrophic. But it was also stated that the enrichment of river waters in nutrients does not always lead to a corresponding increase of primary production. Chlorophyll content indicated the mesotrophic conditions, and in some cases - oligotrophic conditions. These findings correlate with the results obtained by other authors concerning the limiting role of nitrogen and phosphorus in eutrophication process in the rivers [16, 25]. Assessment of trophic status made on the basis of ITS in the majority of measurement points agrees with the assessments based on chlorophyll content. It can be explained by the fact that both of these indicators reflects the integrated ecosystem's response to the effects of pressure factors, whereas the content of nitrogen and phosphorus - only the eventuality of plant biomass growth.

The results of preliminary statistical analysis, carried out in order to determine the limiting role of biogenic compounds in the examined measurement points, correlate with the results obtained by other researchers. It is generally recognized, that increased content of nitrogen and phosphorus brings to the intensive algae growth. But increased algae production not always results in accumulation of algae biomass excess. Accumulation of excessive biomass is influenced by a number of different factors, such as light penetration, grazer activity, morphological features and etc. For example, primary production in heavily grazed rivers is either consumed or exported, while reduced grazing activity lead to biomass accumulation and its decomposition [26]. Francoeur [27] provided the following results of studies on limiting role of phosphorus in the process of eutrophication in 237 rivers: in $16.5 \%$ the nitrogen showed a limiting role, $18.1 \%$ - showed the limiting role of phosphorus, $23.2 \%$ - showed the equal role of nitrogen and phosphorus, $5 \%$ - inhibition of the growth of plant biomass as a response to nitrogen or phosphorus load and $43 \%$ showed the lack of response to nitrogen and phosphorus enrichment. However the content of biogenic 
substances is also regulated by a number of abiotic factors. Regional differences may determine the limiting nutrients for water plant growth [9].

The above mentioned considerations mean that nutrient content may not always be a reliable indicator of eutrophication, as trophic status is determined not only by the content of these substances, especially in riverine ecosystems. Other authors also confirm the diversity of eutrophication processes in running waters $[16,26]$. The concentration of chlorophyll-a also may lead to low reliability of trophic level assessment in running water due to its high seasonal volatility, mobility in rivers and large variety of factors determining the development of aquatic vegetation [9, 21, 28]. This indicator can be used rather for eutrophication assessment in so called "chlorophyll-type rivers". In Poland there are only 5 types of such rivers: 21 (great lowland rivers), some rivers of 19 type (lowland sandy-clay rivers), 20 (medium lowland gravel rivers), 24 (small valleys rivers under the influence of peat-forming processes) and 25 (lakes connecting rivers).

Due to the complex nature of eutrophication in running waters further studies are needed in order to verify the preliminary results of the researches.

\section{Conclusion}

The studies presented in this paper were devoted to very complicated problem of trophic state assessment of running waters. The results of statistical analysis based on longterm monitoring data concerning the rivers of different types allowed to verify the possibility of ITS usage and to state its conformance with modern requirements to environmental indicators. It allowed in simple and low-cost way to assess the trophic state and to evaluate the changes and tendency of eutrophication development in different types of rivers during 10-year period. ITS-based approach was also used in order to carry out the preliminary studies on complicated nature of limiting role of total nitrogen and total phosphorus in eutrophication development.

\section{References}

[1] Directive 2000/60/EC of the European Parliament and of the Council of 23 October 2000 establishing a framework for community action in the field of water policy (in Polish: Dyrektywa 2000/60/WE Parlamentu Europejskiego i Rady z dnia 23 października 2000 r. ustanawiająca ramy wspólnotowego działania w dziedzinie polityki wodnej). http://eur-lex.europa.eu.

[2] Council Directive 91/676/EEC of 12 December 1991 concerning the protection of waters against pollution caused by nitrates from agricultural sources (in Polish: Dyrektywa Rady z dnia 12 grudnia 1991 r. dotycząca ochrona wód przed zanieczyszczeniami powodowanymi przez azotany pochodzenia rolniczego 91/676/EWG). http://eur-lex.europa.eu.

[3] Council Directive 91/271/EEC of 21 May 1991 concerning urban waste-water treatment (in Polish: Dyrektywa Rady z dnia 21 maja 1991 r. dotycząca oczyszczania ścieków komunalnych 91/271/EWG). http://eur-lex.europa.eu.

[4] Journal of Laws No. 115, item. 1229, Water Law Act of 18 July 2001 (in Polish: Dziennik Ustaw Nr 115 , poz. 1229, Ustawa z dnia 18 lipca 2001 r. Prawo wodne). http://isap.sejm.gov.pl.

[5] Journal of Laws No 162, item 1008, Regulation of the Ministry of Environment of 20 August 2008 on the classification of the status of surface water (in Polish: Dziennik Ustaw Nr 162, poz. 1008, Rozporządzenie Ministra Środowiska z dnia 20 sierpnia 2008 r. w sprawie sposobu klasyfikacji stanu jednolitych części wód powierzchniowych). http://isap.sejm.gov.pl.

[6] Journal of Laws No. 241 item 2093, Regulation of the Ministry of Environment of 23 December 2002 on the criteria for designation waters susceptibility to pollution by nitrogen compounds from agricultural sources (in Polish: Dziennik Ustaw $\mathrm{Nr}$ 241, poz. 2093, Rozporządzenie Ministra Środowiska 
z dnia 23 grudnia 2002 r. w sprawie kryteriów wyznaczania wód wrażliwych na zanieczyszczenie związkami azotu ze źródeł rolniczych). http://isap.sejm.gov.pl.

[7] European Environment Agency (EEA) Freshwater Eutrophication Assessment. ETC Water Technical Report 2/2010. http://icm.eionet.europa.eu.

[8] Measuring progress towards a more sustainable Europe. Luxemburg: EUROSTAT, Office for Official Publications of the European Communities; 2001. http://epp.eurostat.ec.europa.eu/.

[9] Zheng L, Paul MJ. Effects of eutrophication on stream ecosystems. Tetra Tech Inc.; 2003. http://n-steps.tetratech-ffx.com.

[10] Istvanovics V, Honti M. Efficiency of nutrient management in controlling eutrophication of running waters in the Middle Danube basine. Hydrobiologia. 2012;686:55-71. DOI 10.1007/s 10750-012-0999-y.

[11] Smith VH. Eutrophication of freshwater and coastal marine ecosystems. A global problem. Environ Sci Pollut. 2003;10:126-139. https://www.tcd.ie.

[12] Biggs BJF. Eutrophication of steams and rivers: dissolved nutrient - chlorophyll relationships for bentic algae. Jornal of the North American Bentholog Soc. 2002;19(1):17-31. https://www.deq.idaho.gov.

[13] Bagotsky SV. Mathematical model describing auto-oscillation in concentrations of toxins secreted by algae. Biofizika. 1991;36(1):117-121.

[14] Hynes HBN. The Biology of Polluted Waters. Liverpool Univ. Press; 1960, from http://www.ibiologia.unam.mx.

[15] Correll DL. Phosphorus: a rate limiting nutrient in surface waters. Poultry Sci. 1999;78:674-682. http://ps.oxfordjournals.org.

[16] Dodds WK. Eutrophication and trophic state in rivers and streams. Limnolog Oceanogr. 2006;51(1):671-680. DOI: 10.4319/lo.2006.51.1_part_2.0671.

[17] Odum EP. Fundamentals of Ecology. Third edition. Philadelphia-London-Toronto: W.B. Saunders Company; 1971.

[18] Rossolimo LL. Changes of limnetic ecosystems under the influence of anthropogenic factors (in Polish: Zmiany ekosystemów limnicznych pod wpływem czynników antropogenicznych). Moskwa: Izd. „Nauka”; 1977.

[19] Zheng-Gang J. Hydrodynamics and Water Quality: Modeling Rivers, Lakes and Estuaries. Hoboken, New Jersey: John Wiley and Sons, Inc.; 2008. DOI: 10.1002/9780470241066.

[20] Neverova-Dziopak E. Ecological aspects of surface water protection (Ekologiczne aspekty ochrony wód powierzchniowych). Rzeszów: Oficyna Wyd. PR; 2007.

[21] Neverova-Dziopak E. Fundamentals of Anthropogenic Eutrophication Management (Podstawy zarządzania eutrofizacją antropogeniczną). Kraków: Monografia, Wyd. AGH; 2010.

[22] Fundamentals on environmental measurements. Water quality: dissolved oxygen, from http://www.fondriest.com/environmental-measurements/parameters/water-quality.

[23] Mitraki C, Crisman TL, Zalidis G. Lake Koronia, Greece: Shift from autotrophy to heterotrophy with cultural eutrophication with progressive water level reduction. Limnologica-Ecology and Manage of Inland Waters. DOI 10.1016/S0075-9511(04)80029-X.

[24] Kowalewski Z. Verification of the integral criterion applicability for the assessment of trophic status of waters [PhD Thesis]. (Weryfikacja możliwości zastosowania integralnego kryterium do oceny stanu troficznego wód). Kraków: AGH; 2012.

[25] García de Jalón D, González del Tánago M. River restoration in Spain: Theoretical and practical approach in the context of the European Water Framework Directive. Environ Manage. 2012;50(1):123-39. DOI: 10.1007/s00267-012-9862-1.

[26] Lamberti GA, Ashkenas CV, Gregory AD, Steinman SV, Macintire CD. Productive capacity of periphyton as a determinant of plant-animal interactions in stream. Ecology. 1989;70:1840-1856. DOI: $10.2307 / 1938117$.

[27] Francoeur SN. Meta-analysis of lotic nutrient amendment experiments: detecting and quantifying subtle responses. J N Am Benthol Soc. 2001;20:515-528. http://www.jstor.org/stable/1468034.

[28] Goering JJ, Wallen DD, Nauman RM. Nitrogen uptake by phytoplankton in the discontinuity layer of the eastern subtropical Pacific Ocean. Limnol Oceanogr. 1970;15:789-796. DOI: 10.4319/1o.1970.15.5.0789. 


\title{
METODOLOGICZNE PROBLEMY OCENY STANU TROFICZNEGO WÓD PŁYNĄCYCH
}

\author{
Katedra Kształtowania i Ochrony Środowiska, AGH Akademia Górniczo-Hutnicza, Kraków
}

\begin{abstract}
Abstrakt: Szczegółowa analiza stosowanych w różnych krajach sposobów oceny stanu troficznego wód powierzchniowych pozwoliła wnioskować, że obecnie nie ma uniwersalnej metodologii, a stosowane metody posiadają różnorodne mankamenty i nie zawsze pozwalają uzyskać wiarygodne wyniki oceny. Analiza pokazała również, że zdecydowana większość metod oceny jest opracowana dla wód stojących i stref przybrzeżnych mórz. Zdecydowanie brakuje wiarygodnych i prostych sposobów oceny stanu troficznego wód płynących. W związku z tym, że eutrofizacja jest procesem, który charakteryzuje się dużą dynamicznością i zależy od zespołu wielu współdziałających między sobą czynników morfologicznych, hydrologicznych, hydrobiologicznych, klimatycznych i innych, ocena stanu troficznego wód, a zwłaszcza w rzekach i strumieniach, jest zadaniem bardzo skomplikowanym. Metoda oceny zaproponowana przez autorów artykułu zasadniczo różni się od metod tradycyjnych i opiera się na definicji stanu troficznego jako wyniku stanu bilansu biotycznego w wodach. Przedstawiono możliwość oceny statusu troficznego wód płynących na podstawie autorskiego wskaźnika ITS (Index of Trophic State) oraz wstępne wyniki badań nad kluczowymi czynnikami ograniczającymi proces eutrofizacji w rzekach różnego typu w oparciu o wskaźnik ITS.
\end{abstract}

Słowa kluczowe: wody płynące, eutrofizacja, metodologia oceny, bilans biotyczny, wskaźniki poziomu troficznego 